\title{
Relationship Between Qulqula Conglomerate Formation and Red Bed Series, at Qulqula Area, NE-Iraq
}

\author{
Kamal H. Karim Mushir M. Baziany \\ Department of Geology \\ College of Science \\ Sulaimani University
}

(Received 8/10/2006, Accepted 21/1/2007)

\begin{abstract}
Previous studies considered Qulqula Conglomerate Formation and Qulqula Radiolarian Formation as two units that comprise Qulqula Group. They mentioned that the former formation overlies the later gradationally. The type sections of both formations occur at Kulkula Gorge, about $25 \mathrm{~km}$ to the northeast of Ranyia Town. These studies indicated the age Qulqula Conglomerate Formation as Albian-Cenomanian and referred to deposition in deep basin of high tectonic activity. This tectonic is punctuated by deposition of the wildflysch which is represented by $1200 \mathrm{~m}$ of conglomerate, sandstone and shale.

However, during restudy of the lithology, stratigraphy and facies of Qulqula Conglomerate Formation at type section, any of the above characteristics are not observed. Conversely, many new data are recorded for the first time that revised lithology; stratigraphic position and age of the formation as concerned to previous ones. As it is shown the lithology of the formation is similar to the lithology of unit three of the Red Bed Series. This is proved by the following lines of evidence: Lateral tracing of the formation to the type locality of the Red Bed Series (Suwais village), indicating of their mergence with each other in a depositional condition near the village. Several species of Alveolina and Nummulite large forams are found in the gravels and boulders of the formation at the type locality. The age of these forams are Eocene; therefore the age of Qulqula Conglomerate Formation is changed to yonger than Eocene. The wildflysch facies as cited before is nothing except the molasse of Red Bed Series as it contains same alternation of lensoidal conglomerate and sandstone with some shale and claystone. This study suggests modification stratigraphical position of the formation in the type area so that it must be included in the Red Bed Series and Qulqulq Conglomerate Formation must be abandoned.
\end{abstract}




\section{علافة تكون الفلفلة المدلكاتي معسلسلة اللبقلت الحمراء في مطاقة الفلةقشملششرق العرق}

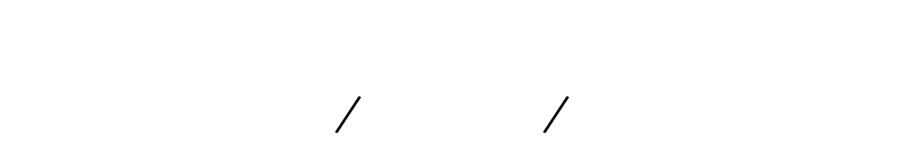

الملخص

اوضحت الدرلسلت للساقة أن تكوين القلقة المدملكاني هو جزء من مجموعة القلقلة والذي الفي الفي

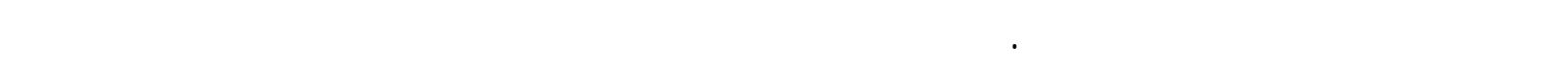

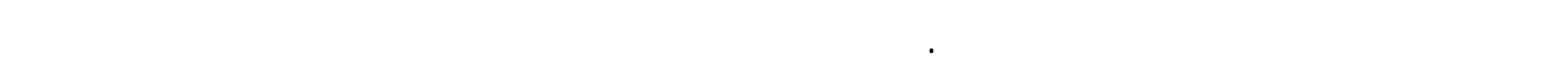

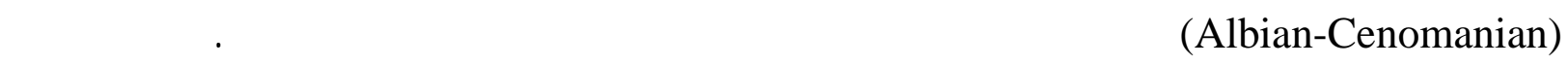

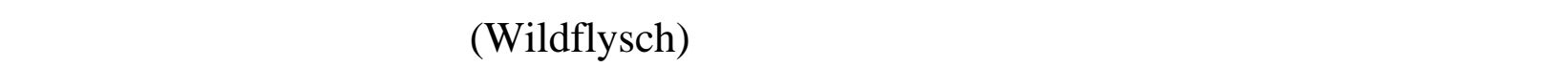
المدملكلت والحجر الرملي والطفل.

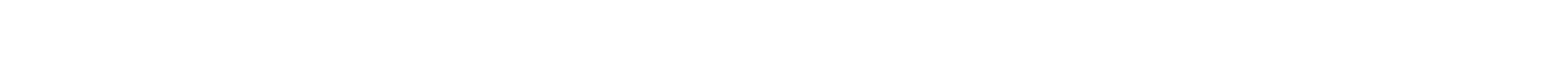

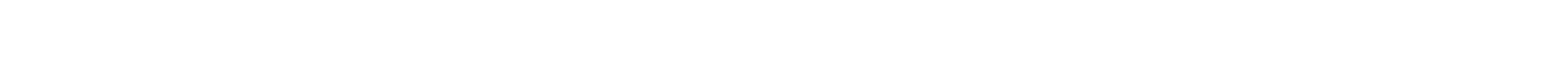

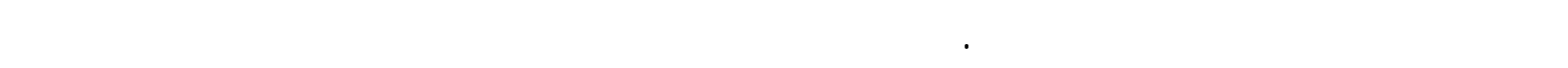

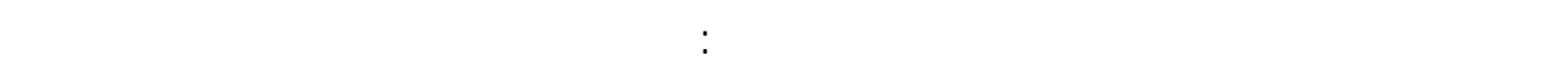

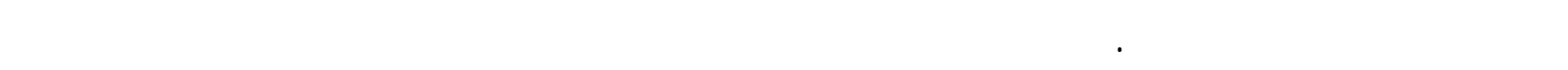

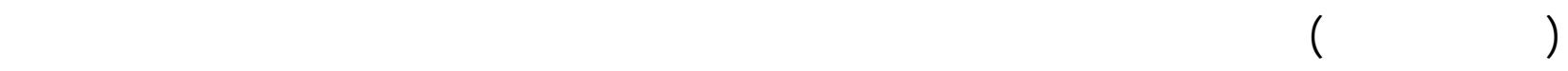

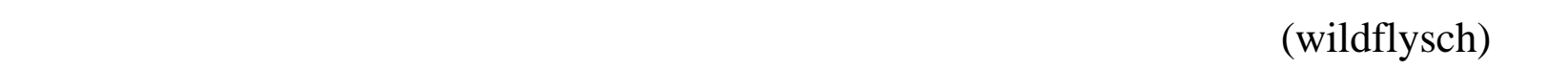

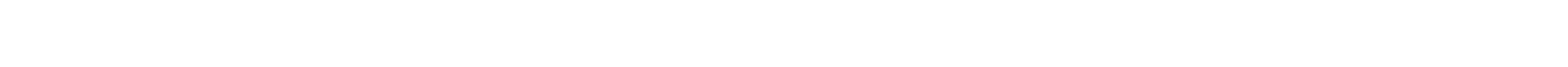

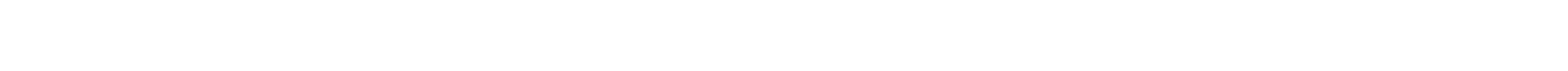
الحمراء.

\section{INTRODUCTION}

The Qulqula Group includes Qulqula Radiolarian Formation and Qulqula Conglomerate Formation; with latter formation overlying the former formation in a gradation condition (Buday, 1980, Sissakian, 2005, Jassim and Goff, 2006,). These authors mentioned that Qulqula Conglomerate Formation was first described by Bolton in 1955, but a more precise definition and description was given by the same author in 1958 . No changes were introduced in the definition of the formation since that time. In addition, no fossils were reported till now and the contacts of the formation are not precisely delineated.

From the description of the former author and from amenable reconnaissance survey it appears that all the conglomerates that overlies Qulqula Radiolarian Formation is called Qulqula Conglomerate Formation. Therefore, the present study is dealing with one of the outcrops of these conglomerates at type locality. During the fieldwork many features are observed in the type area, by the present authors that give sense of disagreements with the 
previous ideas about the formation. These features include sedimentary structures, lithology, and stratigraphic position. The stratigraphy is not clear as regarded to the vertical and lateral relation with the other units. Therefore the present study is aiming to re-study the formation with respect to stratigraphy and lithology.

\section{LOCATION AND GEOMORPHOLOGY}

The studied section is located within Sulaimaniya Governorate in northeastern Iraq at Qandil Mountain toe in the Qulqula (locally Kulkula) Gore and directly to north of Kulkula village. The section can be seen directly to the west of the gorge on the Maradu River (small permanent stream) about $25 \mathrm{~km}$ to the northeast of Ranyia Town (Fig.1, 2 and 3). The type section is located at latitude $\left(36^{\circ} 21^{-} 23^{-}\right)$and longitude $\left(45^{\circ} 10^{-} 04^{-}\right)$. At this area Sissakian (1997) has shown the outcrops of the formation on the geological map of Arbeel and Mahabad Quadrangles area (scale: 1:250000). On this map the formation covered about $5 \mathrm{~km}^{2}$ and exposed at the front of the outcrop of Qulqula Radiolarian Formation.

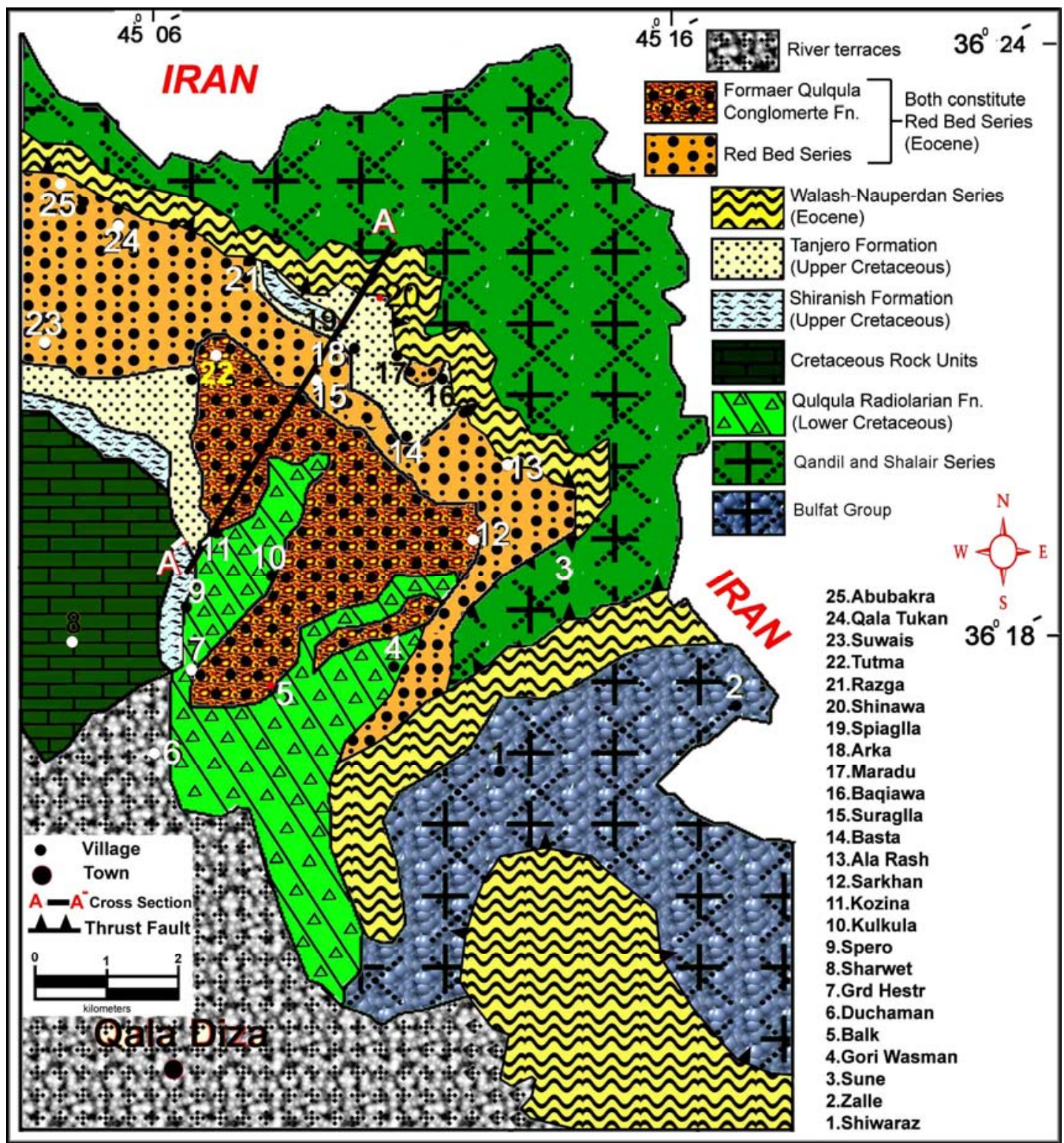

Fig. 1: Geological map of that a part of Qandil Mountain that surrounds the type section of Qulqula Conglomerate Formation. (Modified from Sissakian, 1997 and 2000). 


\section{TECTONIC SETTING AND DEPOSITIONAL HISTORY}

The studied area is located within the western Zagros Fold- Thrust Belt, which is developed from the basin fill of the Neo-Tethys and collision of the Iranian and Arabian plate (Buday, 1980). Structurally, the studied area is located within imbricated and thrust zone (Buday and Jassim, 1987). The same authors, in their tectonic subdivision of Iraq put the studied area in the Qulqula-Khuakurk Subzone. The area is characterized by obscured anticlines and synclines which have been stacked together as very thick and tight packages which were overturned toward southwest or even overthrusted. Stocklin (1974) called the studied area as (Crushed Zone). This is because it is highly deformed where fractures, faults and folds can be recognized on microscope scale.

Buday (1980) mentioned that the formation has been deposited during AlbianCenomanian and controlled by mid-Cretaceous orogeny. In contrast to this idea Karim and Surdashy (2005) mentioned that deformation and development of the studied area has began since Campanian and at this age the continental part of Iranian and Arabian plate is collided and a Foreland basin was formed. By continuous advancing (thrusting) of the Foreland and hinterland of the Iranian plate the sediments inside the basin were progressively deformed and more sediment has been supplied to basin. This type of deformation and sedimentation was continuous till, the end of Tertiary and since then the studied area gained the present geological setting which is now highly modified by weathering and erosion.

\section{DESCRIPTION OF THE FORMATION AT THE TYPE AREA}

According to Bolton (1955, in Buday, 1980) the section of type locality consists of thick lenticular beds of conglomerates which are composed of pebbles and small boulders of limestone and to a lesser extent of chert. These conglomerates are interbedded with grey shale and also with individual beds of oolitic detrital limestone and white chert. The thickness of this formation is about $1200 \mathrm{~m}$.

Baziany (2006) and the present authors have ascertained the above lithology but oolitic detrital limestone is not recognized. The conglomerate beds consist of subangular pebbles and boulders of light colored chert, grey and milky limestone. In addition to chert and limestone clasts, it contains rare igneous pebbles (Table 1 and Fig. 5 and 10). The conglomerate beds are interbedded with dark grey sandstone (occasionally pebbly) (Fig. 3 and 6B) and lenticular brown silty claystone bed of 20-70 cm thick (Fig. 7).

The conglomerate is identified compositionally and texturally as polymictic and orthoconglomerate which is, as mentioned above, contain more than one type of rock clasts. According to texture classification of Pettijohn (1975) it called orthoconglomerate as it is grain supported and contain less than $25 \%$ matrix (Table 1). The formation at Kulkula gorge is located directly above the Qulqula Radiolarian Formation with angular unconformity (Fig. 2), while toward the west of the gorge, near Tutma village it is overlies the Tanjero Formation (Fig. 1).

The clasts exist in different size which range from pebbles to blocks in size, some of the limestone clasts consist of blocks (more than $22 \mathrm{~cm}$ in diameter). They have the shape of bladed, oblate and some of them have prolate (elongate) shape. The gravels are generally angular to sub angular and have low spherecity with poor sorting. This indicated that these lenticular beds of conglomerate are deposited close to the source area and suffered little transportation. The igneous clasts are rounded, with moderate to high sphericity, while limestone fragments are subangular and have low to moderate sphericity, whereas the chert grains show more angularity and less sphericity than igneous and chert. 


\section{DESCRIPTION OF NUMMULITE AND ALVEOLINA FORAMS}

The most surprising and important finding during this study is recognition of both Nummulite and Alveolina benthonic forams (Fig. 8 and 9) in the Qulqula Conglomerate Formation. Both fossils exist together in the pebble and boulder of the conglomerate at the middle of the Kulkula Gorge. Thin section study showed that these fossils are exclusive to the clasts of limestone and when cross-referenced to those published by Al-Hashimi and Amer (1985), Surdashy (2001) and Al-Barzinjy (2005), it becomes clear that the limestone gravels and boulders belong to the Eocene Nauperdan Group. Therefore the age of this conglomerate must be changed from Albian-Cenomanian, as indicated by Buday (1980) and Sissakian (2005), to an age that younger than Eocene.

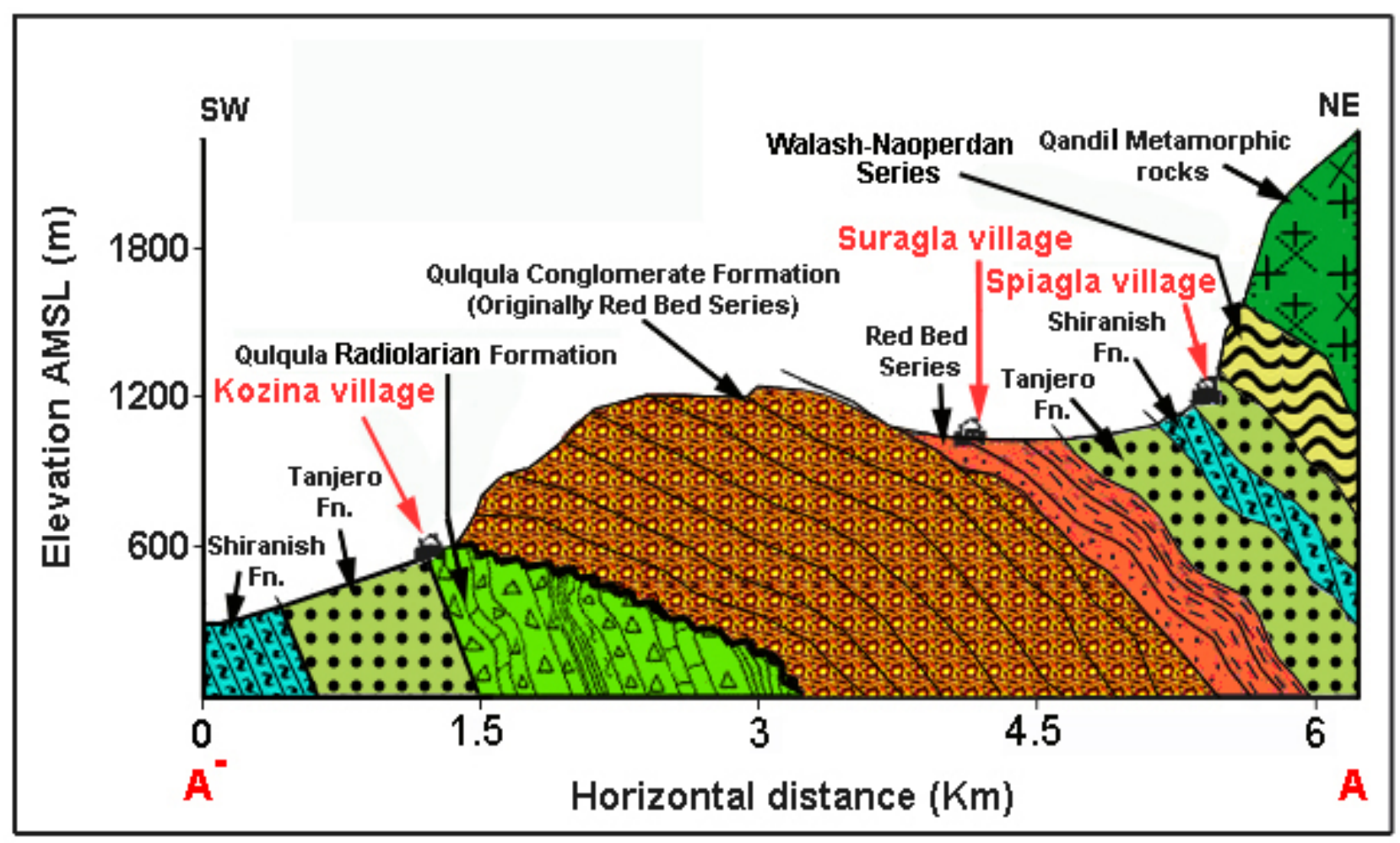

Fig. 2: Geological cross section of Kulkula gorge as can be seen along left side of Marado valley (from Baziany,2006). 


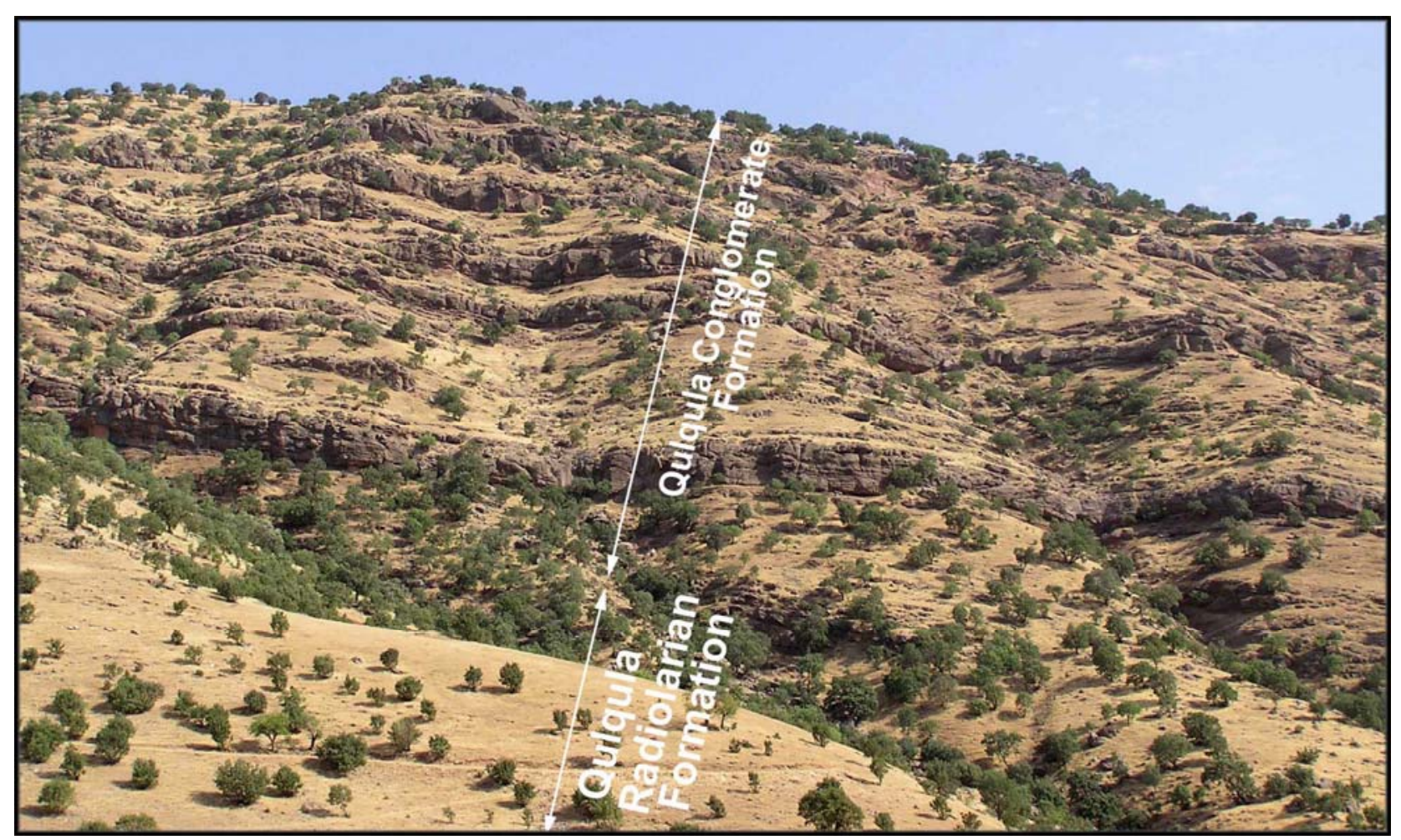

Fig. 3: Left side of Kulkula gorge (Type section), at $17 \mathrm{~km}$ north of Qala Diza town which shows outcrop of Qulqula Conglomerate Formation (consist of thick beds of lensoidal conglomerate with interbedded sandstone).

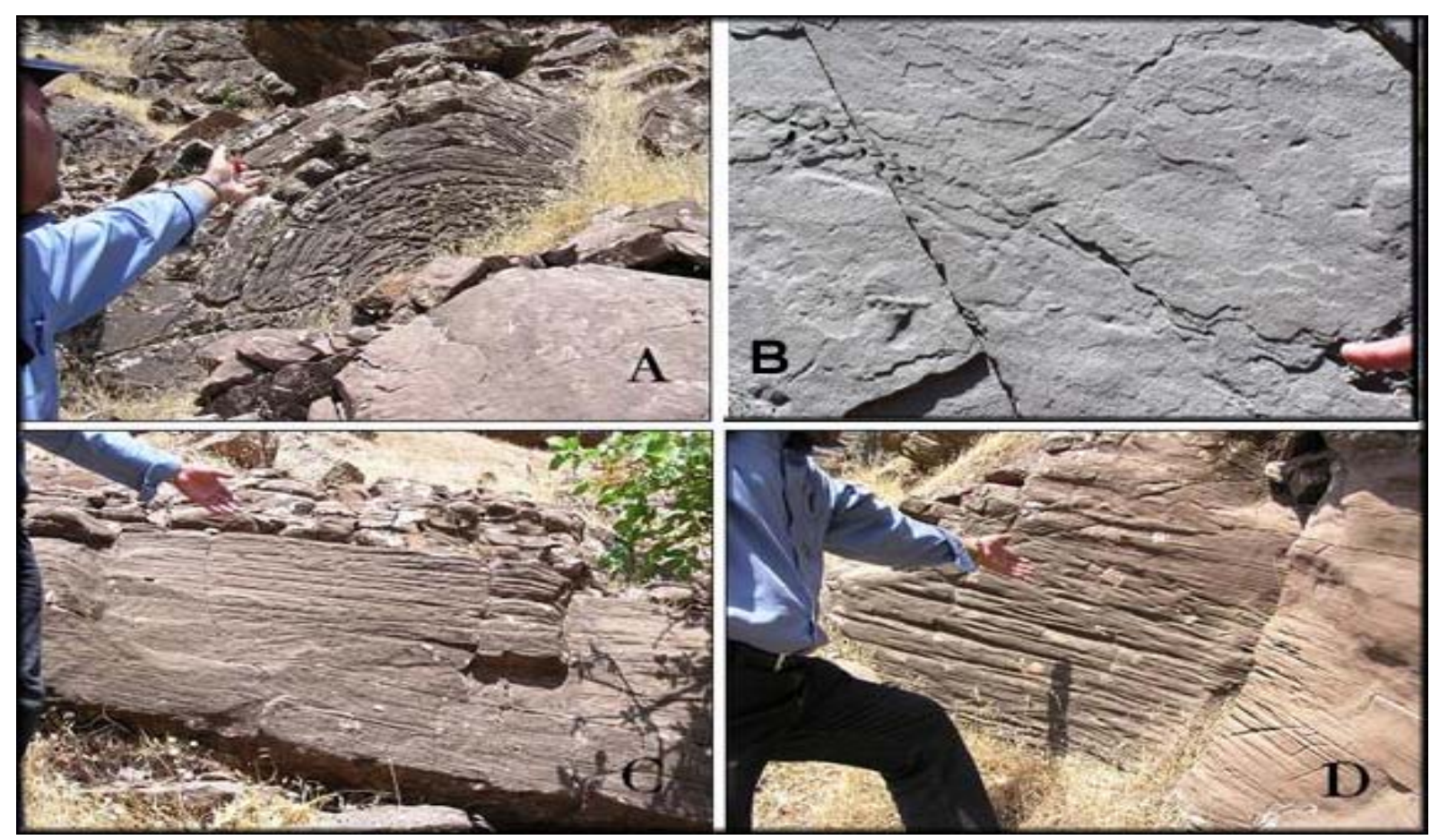

Fig. 4: Different features of the sandstone beds of the Qulqula Conglomerate Formation at type locality:

A: Cross bedded sandstone which is later folded.

$\mathrm{B}$ : Top of a grey medium grain sandstone showing parting lineation.

$\mathrm{C}$ and D: Horizontal stratification changes to cross lamination occasionally. 


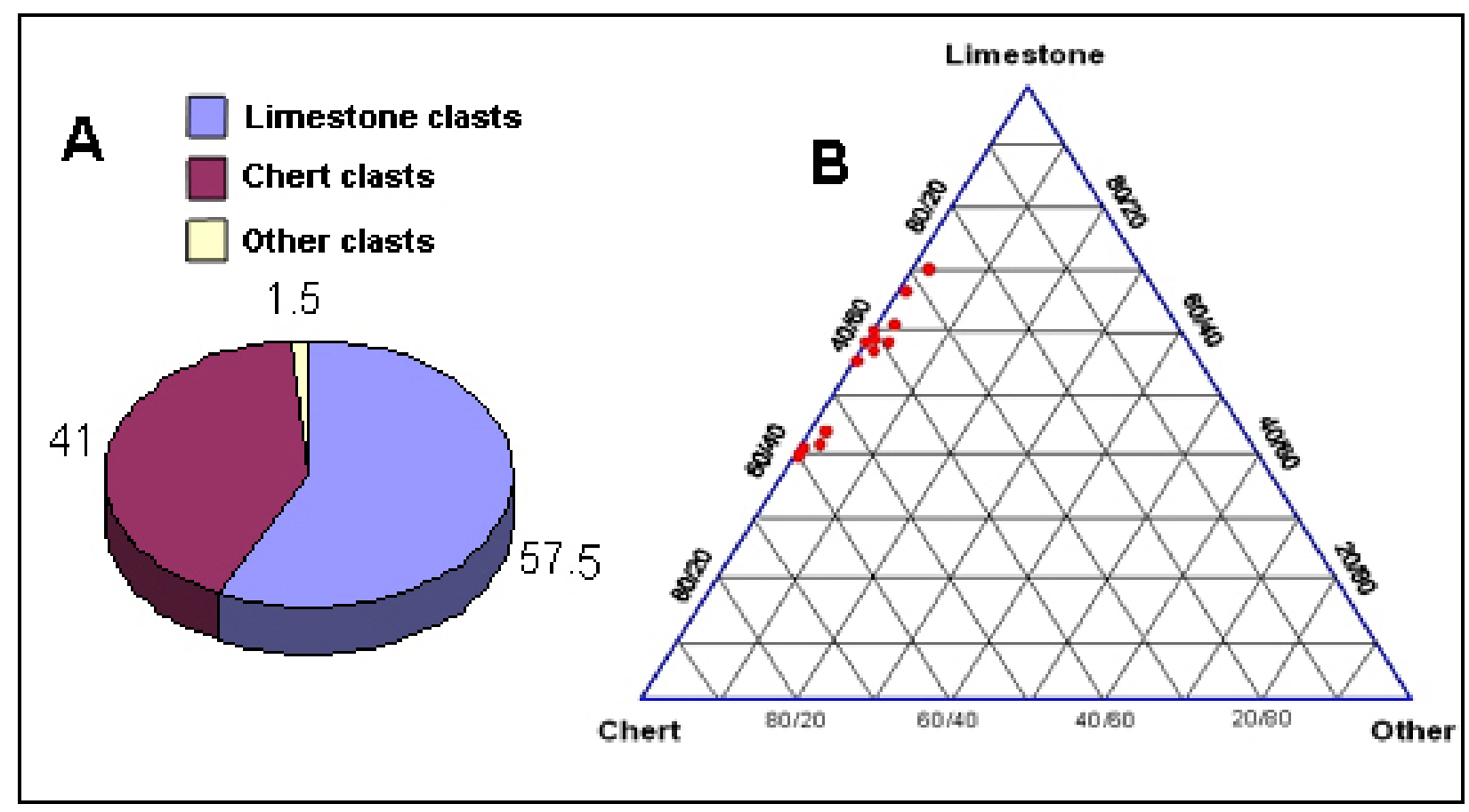

Fig. 5: A) Lithologic constituents of conglomerate beds of Qulqula Conglomerate Formation at Qandil area.

B) Average percentages of different conglomerate clasts at Qandil area. Note: Others $=$ Igneous and Metamorphic clasts.

\section{STRATIGRAPHIC POSITION O F THE FORAMS BEARING CONGLOMERATES}

The finding of the Eocene Nummulite and Alveolina large forams encouraged the acquisition of further varietal data. During this work, the lateral tracing of the formation was conducted in order to elucidate the stratigraphic relation of the formation in the Kulkula gorge and surrounding area with other units. This tracing is done with a radius of more than $20 \mathrm{~km}$ both along the strike and dip of the strata. When the formation is traced laterally to the northwest, for about $20 \mathrm{~km}$, Qulqula Conglomerate Formation merges with the conglomerate of Red Bed Series. This attitude is seen near Suwais village where the type locality of Red Bed Series is located. Likewise this configuration is repeated when the formation is laterally traced toward southeast (toward Sarkhan villages) where the formation merges into Red Bed Series also (Fig. 1). The close inspection proved that the attitude is depositional and has no any relation to the tectonic juxtaposition or faulting. When the conglomerate is compared lithologically and stratigraphically with that of the Red Bed Series they showed high degree of similarity in their type localities. The previous studies of Al-Mehaidi (1975), Buday (1980), and Al-Barzinjy (2005) are also used for comparison.

According to the above: finding of Eocene forams, merging with Red Bed Series and lithologic similarities it can be decided that the Qulqula Conglomerate Formation from the stratigraphy of the type area be deleted. Moreover, the outcrop described by Sissakian (1997) in the type area must be coupled with the Red Bed Series. This is because Al-Omari and Sadiq (1977) and Al-Barzinjy (2005) found the same forams in the Red Bed Series in the Chuarta area (thus making leading contribution to this endeavor). Field survey showed that at distance of about $7 \mathrm{~km}$ the underlying formation change from Qulqula Radiolarian Formation, at Kulkula gorge, to Tanjero Formation near Tutma village. This change of the underlying formation is due to the interplay of tectonics and sedimentation with subsequent different erosion rates. 


\section{SANDSTONES OF THE KULKULA GORGE SECTION}

In the Kulkula gorge section there are intervals of well bedded laminated sandstones with a thickness of 1-5 m and sandwiched between thick conglomerate beds (Fig.3 and 4). They are grey in color and contain parallel and cross lamination. The sandstones beds are medium in toughness and shaped with beautiful ornamentation as a tombstone by villagers in the area. Petrographically, they consist of medium to coarse grained lithicarenite. The classifications of Folk (1974) Pettijohn (1975) and Al-Rawi (1982) (Fig. 11) are used for plotting them on the equilateral triangles with calcite cement. Compositionally, they contain about $50 \%$ chert, $30 \%$ limestone, $5 \%$ igneous and $5 \%$ other grains (clasts) (Table. 2 and Fig. 10). It is worthy to mention that one of the slides showed exceptionally high content of angular quartz (Fig.10A). As concerned to texture, they are moderately sorted and sub-rounded with low sphericity. Fig. 3 shows the conglomerate forming scarps (bare outcrops) while the soil covered intervals area consist mainly of sandstone or pebbly sandstones.

\section{MODIFICATION OF THE GEOLOGICAL MAP OF THE TYPE AREA}

Sissakian (1997) has shown the outcrops of the formations on the geological map of the Arbeel and Mahabad Quadrangles area (scale: 1:250000). On this map the stratigraphic units are shown which are exposed around the type section. The Qulqula Conglomerate Formation covers about $5 \mathrm{~km}^{2}$ and exposed as northwest-southeast elongate spot. On this map, it is shown that Qulqula Conglomerate Formation is exposed at the south of outcrops of Qulqula Radiolarian Formation. In the present study the map is modified as shown in Figure (1).

The modification includes: 1) Replacement of the Qulqula Conglomerate Formation by Red Bed Series. 2) The outcrop of the Qulqula Radiolarian Formation is shifted as to occur to south of the former Qulqula Conglomerate Formation but not at the north as shown by Sissakian (1997). The subterposition of Red Bed Series beneath Tanjero Formation and Shiranish Formations, is in agreement with actual geological setting of the area.

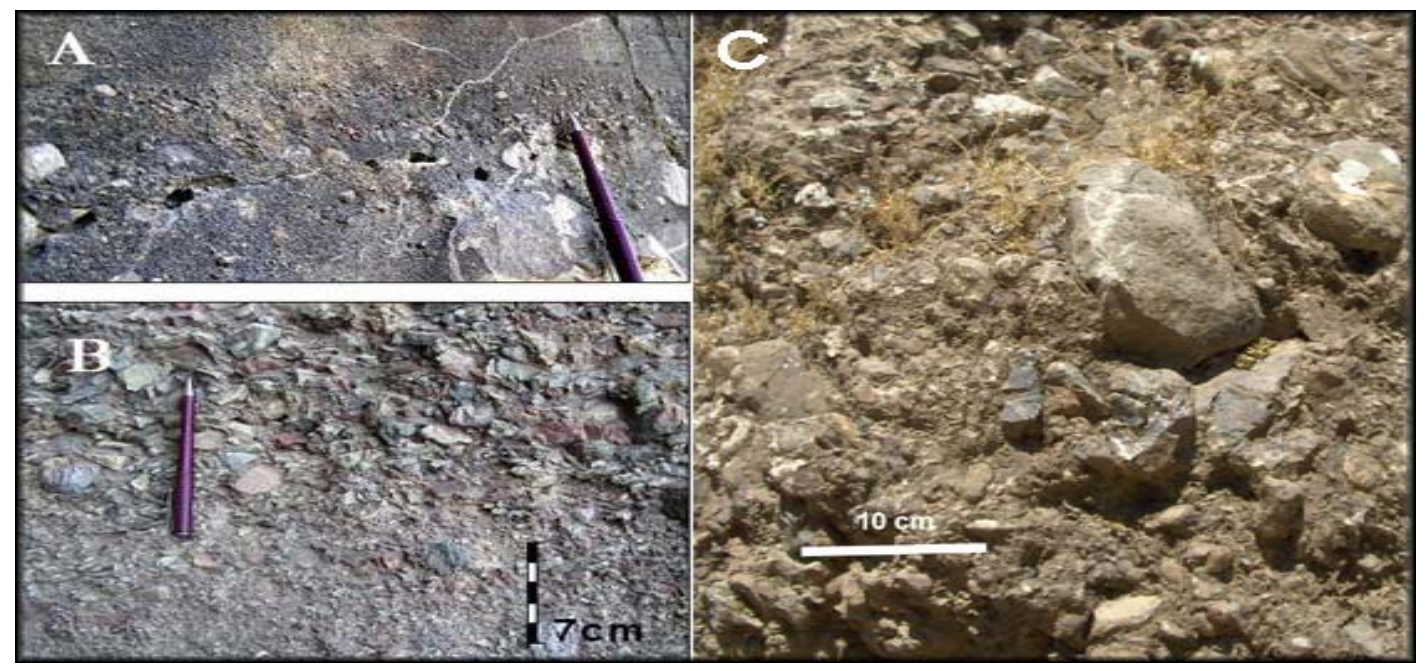

Fig. 6: Pebbly sandstone, coarsening upward conglomerate and boulder conglomerate as can be seen in photos A, B and C, Left side of Kulkula Gorge. 


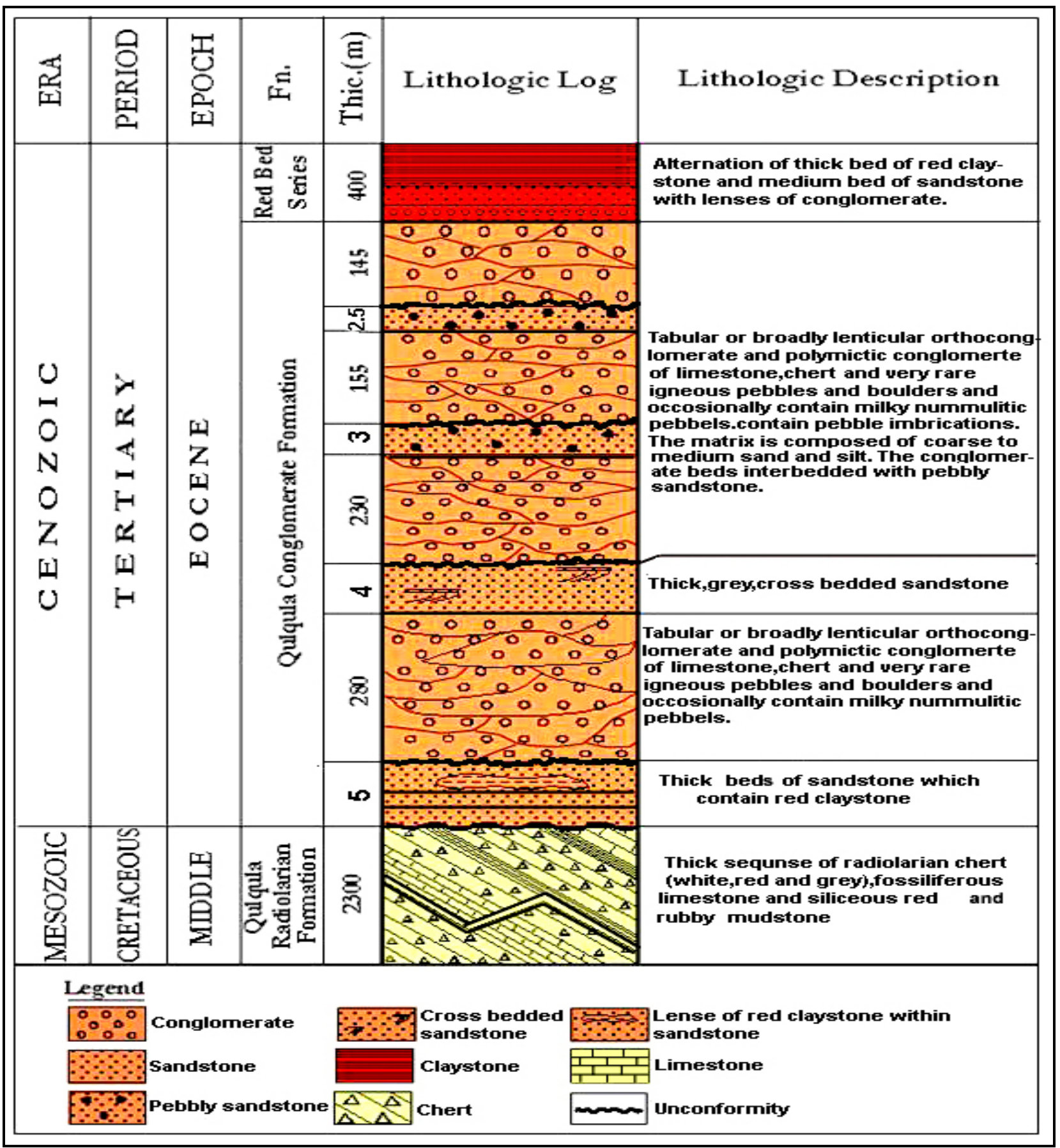

Fig. 7: Stratigraphic column of Kulkula gorge (Type section) at Qandil mountain toe (not to scale). 


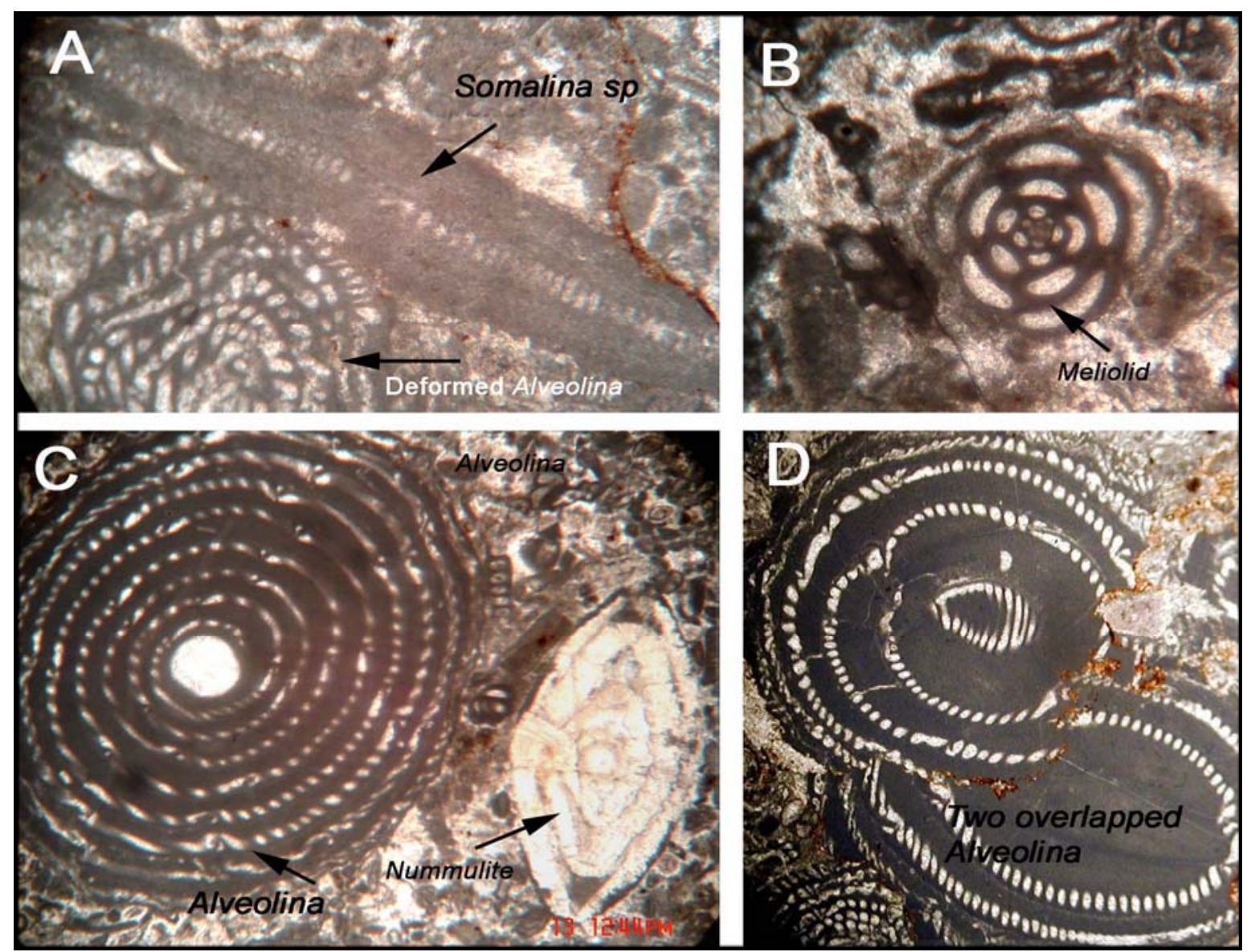

Fig. 8: Different species of Eocene large forams: Alveolina, Nummulites and Somalina $s p$ which are found in the pebbles and boulders of Qulqula Conglomerate Formation in type section gorge. A: S. 10, X40, PPL, B: S.15. X60, PPL. C: S30, X40, PPL. D: S31, X30, PPL.

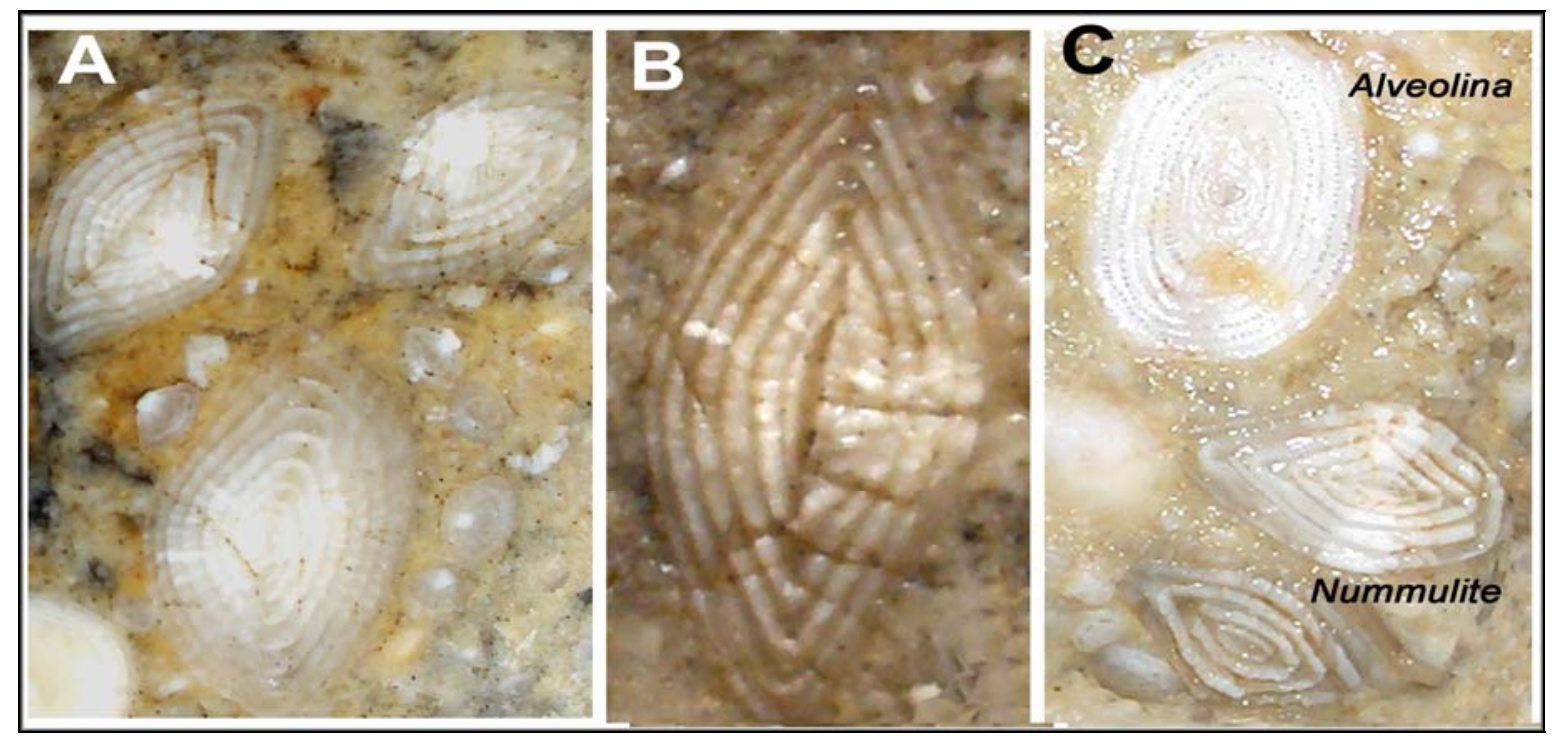

Fig. 9: Different species of Eocene benthonic foraminiferas (Nummulite and Alveolina) that are found in limestone pebbles of Conglomerate of Qulqula Conglomerate Formation, at type section. A: S. 31, X5 N.L,; B:34, X5, N.L, ; C:35, X5 , N.L. ( photo taken by stereo-microscope). 

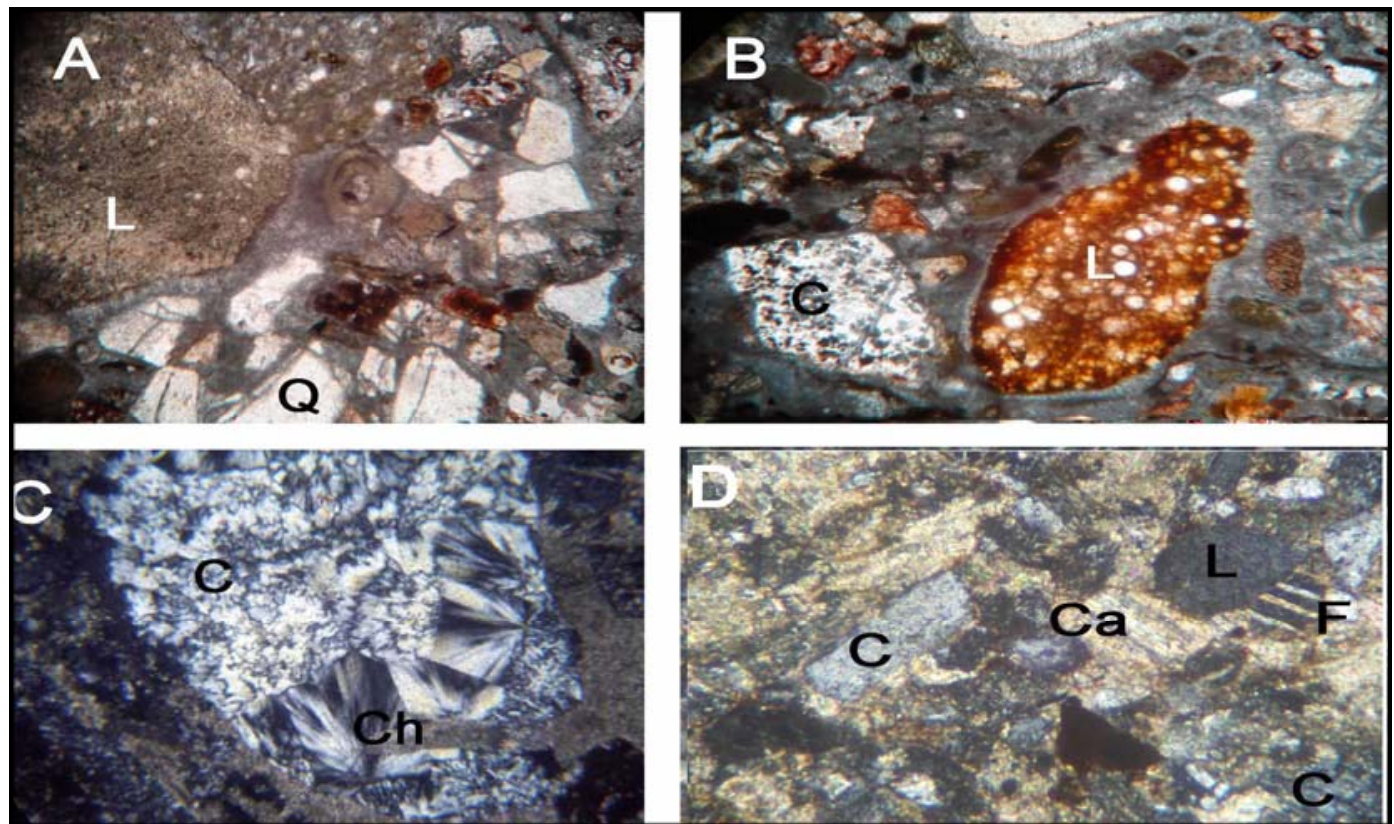

Fig. 10: A:Lithic arenite sandstone of Kulkula gorge contains about $25 \%$ angular quartz grains, S. 44, X40, PPL. B:Radiolarian fossil bearing bituminous limestone grain and cherts, S.48, X40, PPL., C: Chalcedony, S. 50, X 40, PPL., D:feldspar as can be seen in the center right of the photo, S. 21, X 40, PPL.; C: Chert, L: Limestone, Q: Quartz, Ch: Chalcedony, F: Feldspar, Ca: Calcite.

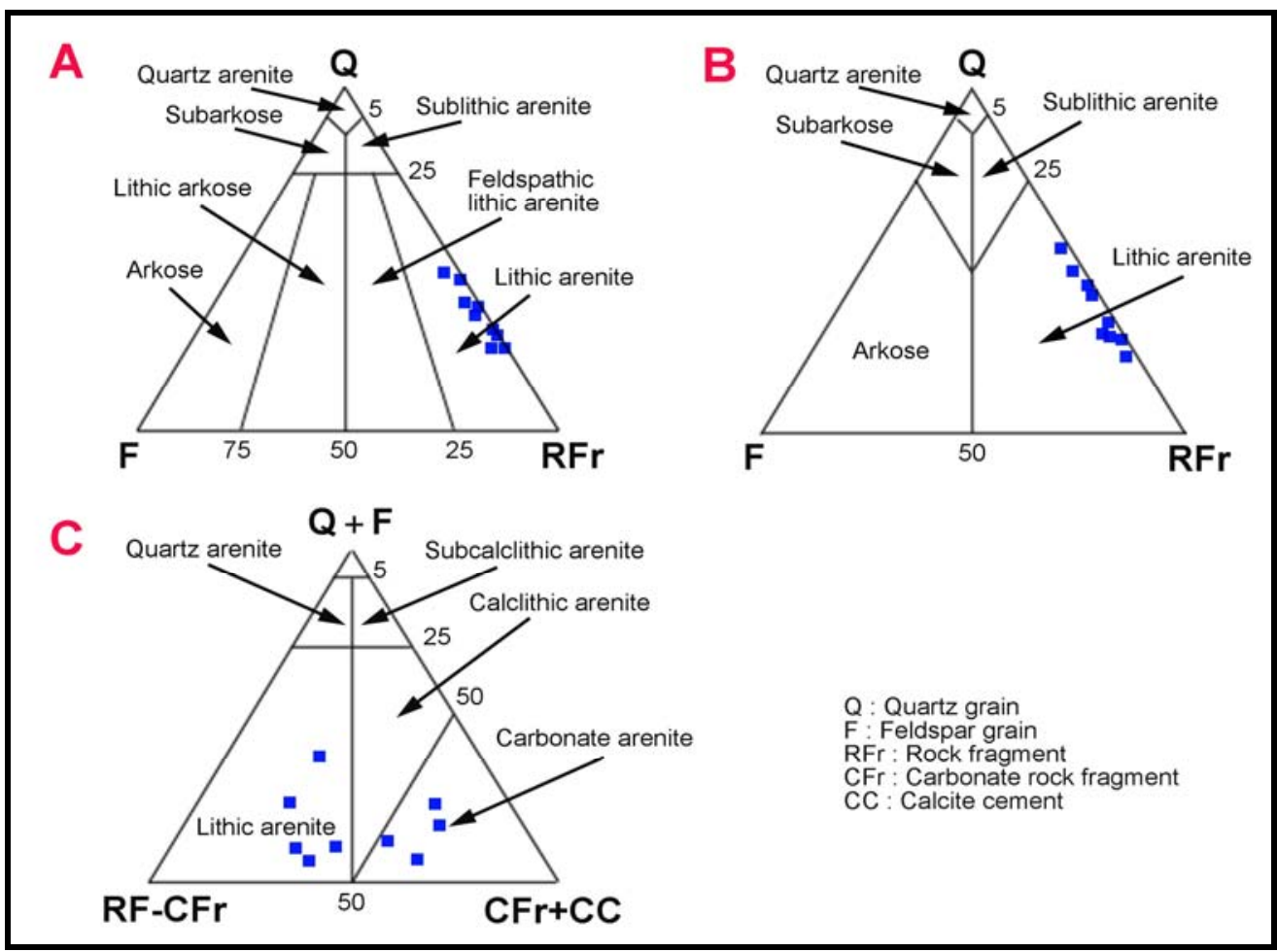

Fig. 11: Classification of sandstone of which interbedded the conglomerate beds of Qulqula Conglomerate Formation, at type section, according to A-Folk, 1974, B-Pettijohn, 1975, C-Al-Rawi, 1982. 
Table 1: Location, percentage of constituent, sorting and roundness and nomenclature of Conglomerate, based on Pettijohn (1975), at Qandil area.

\begin{tabular}{|c|c|c|c|c|c|c|c|c|}
\hline \multirow[b]{2}{*}{ Location } & \multicolumn{4}{|c|}{ Constituent \% } & \multirow{2}{*}{$\begin{array}{c}\begin{array}{c}\text { Sorting } \\
\text { and } \\
\text { Roundness }\end{array} \\
\end{array}$} & \multicolumn{3}{|c|}{ Nomenclature based on } \\
\hline & Lst. & $\begin{array}{l}\text { Grain ty } \\
\text { Chert }\end{array}$ & $\frac{\text { e }}{\text { Other }}$ & Matrix & & Tex. & Comp. & Source \\
\hline $\begin{array}{l}\text { Kulkula gorge } \\
\text { N } 36^{\circ} 20^{-} 19^{=} \\
\text {E } 45^{\circ} 10^{-} 16^{=}\end{array}$ & 55 & 26 & 1 & 18 & $\begin{array}{l}\text { Bad and } \\
\text { Subangular }\end{array}$ & $\begin{array}{c}\text { Ortho } \\
\text { conglomerate }\end{array}$ & $\begin{array}{l}\text { Polymictic } \\
\text { conglomerate }\end{array}$ & $\begin{array}{l}\text { Extraformational } \\
\text { conglomerate }\end{array}$ \\
\hline $\begin{array}{l}\text { Kulkula gorge } \\
\text { N } 36^{\circ} 20^{-} 35^{=} \\
\text {E } 45^{\circ} 10^{-} 11^{=}\end{array}$ & 49 & 29 & 2 & 19 & $\begin{array}{l}\text { Bad and } \\
\text { Subangular }\end{array}$ & $\begin{array}{c}\text { Ortho } \\
\text { conglomerate }\end{array}$ & $\begin{array}{c}\text { Polymictic } \\
\text { conglomerate }\end{array}$ & $\begin{array}{l}\text { Extraformational } \\
\text { conglomerate }\end{array}$ \\
\hline $\begin{array}{l}\text { Kulkula gorge } \\
\text { N } 36^{\circ} 20^{-} 13^{=} \\
\text {E } 45^{\circ} 10^{-} 42^{=}\end{array}$ & 48 & 33 & 1 & 17 & $\begin{array}{l}\text { Bad and } \\
\text { Subangular }\end{array}$ & $\begin{array}{c}\text { Ortho } \\
\text { conglomerate }\end{array}$ & $\begin{array}{c}\text { Polymictic } \\
\text { conglomerate }\end{array}$ & $\begin{array}{l}\text { Extraformational } \\
\text { conglomerate }\end{array}$ \\
\hline $\begin{array}{l}\text { Kulkula gorge } \\
\text { N } 36^{\circ} 20^{-} 11^{=} \\
\text {E } 45^{\circ} 11^{-} 27^{=}\end{array}$ & 52 & 35 & 1 & 11 & $\begin{array}{c}\text { Bad and } \\
\text { Subangular- } \\
\text { Subrounded } \\
\end{array}$ & $\begin{array}{c}\text { Ortho } \\
\text { conglomerate }\end{array}$ & $\begin{array}{c}\text { Polymictic } \\
\text { conglomerate }\end{array}$ & $\begin{array}{l}\text { Extraformational } \\
\text { conglomerate }\end{array}$ \\
\hline $\begin{array}{c}\text { Sarkhan } \\
\text { village } \\
\text { N } 36^{\circ} 18^{-} 45^{=} \\
\text {E } 45^{\circ} 09^{-} 38^{=}\end{array}$ & 60 & 23 & 2 & 14 & $\begin{array}{l}\text { Bad and } \\
\text { Subangular }\end{array}$ & $\begin{array}{c}\text { Ortho } \\
\text { conglomerate }\end{array}$ & $\begin{array}{c}\text { Polymictic } \\
\text { conglomerate }\end{array}$ & $\begin{array}{l}\text { Extraformational } \\
\text { conglomerate }\end{array}$ \\
\hline $\begin{array}{c}\text { Sarkhan } \\
\text { village } \\
\text { N } 36^{\circ} 17^{-} 35^{=} \\
\text {E } 45^{\circ} 09^{-} 12^{=}\end{array}$ & 51 & 35 & 1 & 12 & $\begin{array}{l}\text { Bad and } \\
\text { Subangular }\end{array}$ & $\begin{array}{c}\text { Ortho } \\
\text { conglomerate }\end{array}$ & $\begin{array}{l}\text { Polymictic } \\
\text { conglomerate }\end{array}$ & $\begin{array}{l}\text { Extraformational } \\
\text { conglomerate }\end{array}$ \\
\hline $\begin{array}{c}\text { Kozina } \\
\text { village } \\
\text { N } 36^{\circ} 19^{-} 40^{=} \\
\text {E } 45^{\circ} 10^{-} 04^{=}\end{array}$ & 43 & 28 & 0 & 27 & $\begin{array}{c}\text { Bad and } \\
\text { Subangular- } \\
\text { Subrounded }\end{array}$ & $\begin{array}{c}\text { Ortho } \\
\text { conglomerate }\end{array}$ & $\begin{array}{c}\text { Polymictic } \\
\text { conglomerate }\end{array}$ & $\begin{array}{l}\text { Extraformational } \\
\text { conglomerate }\end{array}$ \\
\hline $\begin{array}{c}\text { Kozina } \\
\text { village } \\
\text { N } 36^{\circ} 19^{-} 16^{=} \\
\text {E } 45^{\circ} 09^{-} 30^{=} \\
\end{array}$ & 17 & 24 & 0 & 58 & $\begin{array}{c}\text { Bad and } \\
\text { Subangular- } \\
\text { Subrounded }\end{array}$ & $\begin{array}{c}\text { Para } \\
\text { conglomerate }\end{array}$ & $\begin{array}{c}\text { Polymictic } \\
\text { conglomerate }\end{array}$ & $\begin{array}{l}\text { Extraformational } \\
\text { conglomerate }\end{array}$ \\
\hline $\begin{array}{l}\text { Gori Wasman } \\
\text { N } 36^{\circ} 18^{-} 47^{=} \\
\text {E } 45^{\circ} 09^{-} 56^{=}\end{array}$ & 40 & 26 & 2 & 31 & $\begin{array}{c}\text { Bad and } \\
\text { Subangular- } \\
\text { Subrounded }\end{array}$ & $\begin{array}{c}\text { Ortho } \\
\text { conglomerate }\end{array}$ & $\begin{array}{c}\text { Polymictic } \\
\text { conglomerate }\end{array}$ & $\begin{array}{l}\text { Extraformational } \\
\text { conglomerate }\end{array}$ \\
\hline $\begin{array}{l}\text { Gori Wasman } \\
\text { N } 36^{\circ} 18^{-} 02^{=} \\
\text {E } 45^{\circ} 09^{-} 15^{=}\end{array}$ & 42 & 29 & 0 & 28 & $\begin{array}{c}\text { Bad and } \\
\text { Subangular- } \\
\text { Subrounded }\end{array}$ & $\begin{array}{c}\text { Ortho } \\
\text { conglomerate }\end{array}$ & $\begin{array}{c}\text { Polymictic } \\
\text { conglomerate }\end{array}$ & $\begin{array}{l}\text { Extraformational } \\
\text { conglomerate }\end{array}$ \\
\hline $\begin{array}{l}\text { Gori Wasman } \\
\text { N } 36^{\circ} 18^{-} 29^{=} \\
\text {E } 45^{\circ} 04^{-} 48^{=}\end{array}$ & 31 & 41 & 2 & 26 & $\begin{array}{c}\text { Bad and } \\
\text { Subangular- } \\
\text { Subrounded } \\
\end{array}$ & $\begin{array}{c}\text { Ortho } \\
\text { conglomerate }\end{array}$ & $\begin{array}{c}\text { Polymictic } \\
\text { conglomerate }\end{array}$ & $\begin{array}{l}\text { Extraformational } \\
\text { conglomerate }\end{array}$ \\
\hline $\begin{array}{l}\text { Balk village } \\
\text { N } 36^{\circ} 16^{-} 50^{=} \\
\text {E } 45^{\circ} 08^{-} 18^{=}\end{array}$ & 19 & 23 & 1 & 56 & $\begin{array}{c}\text { Bad and } \\
\text { Subangular- } \\
\text { Subrounded }\end{array}$ & $\begin{array}{c}\text { Para } \\
\text { conglomerate }\end{array}$ & $\begin{array}{c}\text { Polymictic } \\
\text { conglomerate }\end{array}$ & $\begin{array}{l}\text { Extraformational } \\
\text { conglomerate }\end{array}$ \\
\hline $\begin{array}{l}\text { Balk village } \\
\text { N } 36^{\circ} 16^{-} 32^{=} \\
\text {E } 45^{\circ} 08^{-} 17^{=}\end{array}$ & 19 & 28 & 0 & 52 & $\begin{array}{c}\text { Bad and } \\
\text { Subangular- } \\
\text { Subrounded }\end{array}$ & $\begin{array}{c}\text { Para } \\
\text { conglomerate }\end{array}$ & $\begin{array}{c}\text { Polymictic } \\
\text { conglomerate }\end{array}$ & $\begin{array}{l}\text { Extraformational } \\
\text { conglomerate }\end{array}$ \\
\hline
\end{tabular}


Table 2: Petrographic components of sandstone at Qandil area.

\begin{tabular}{|c|c|c|c|c|c|}
\hline \multirow{2}{*}{ Sample } & \multicolumn{5}{|c|}{ Constituent \% } \\
\cline { 2 - 6 } & $\mathbf{Q z}$ & $\mathbf{R F}^{*}$ & $\mathbf{F}$ & Matrix & Cement* $^{* *}$ \\
\hline $\mathbf{Q}_{\mathbf{1}}$ & 41 & 48 & 3 & 2 & 5 \\
\hline $\mathbf{Q}_{\mathbf{2}}$ & 24 & 56 & 2 & 5 & 13 \\
\hline $\mathbf{Q}_{\mathbf{3}}$ & 28 & 60 & 0 & 4 & 8 \\
\hline $\mathbf{Q}_{\mathbf{4}}$ & 23 & 68 & 1 & 2 & 6 \\
\hline $\mathbf{Q}_{\mathbf{5}}$ & 23 & 62 & 3 & 4 & 7 \\
\hline $\mathbf{Q}_{\mathbf{6}}$ & 55 & 31 & 0 & 1 & 13 \\
\hline $\mathbf{Q}_{\mathbf{7}}$ & 22 & 68 & 2 & 2 & 6 \\
\hline $\mathbf{Q}_{\mathbf{8}}$ & 11 & 64 & 2 & 1 & 21 \\
\hline $\mathbf{Q}_{9}$ & 38 & 48 & 0 & 4 & 11 \\
\hline
\end{tabular}

$\mathrm{RF}^{*}$ :Rock fragments (Chert; metamorphic; Igneous; argillaceous; carbonate) Cement $^{* *}:$ (carbonate; ferruginous). Note: Carbonate and Chert rock fragment are more abundant, Q: Qandil area.

\section{CONCLUSION}

This work achieved the following conclusions:

1-The lithology of Qulqula Conglomerate Formation is consisting of thick sequence of pebbles and boulders conglomerate with interbeds of sandstone and rare red claystone.

2-For the first time Eocene Nummulite and Alveolina are found in the limestone pebbles and boulders.

3-Laterally the Qulqula Conglomerate Formation merges and unites lithologically and stratigraphically with the Red Bed Series.

4- The age of the formation is changed from Albian-Cenomanian to younger than Eocene and the Qulqula Conglomerate Formation is consigned to the Red Bed Series in the type area.

5-Therefore, it is strongly recommended to abandon the formation name and be consigned to the Red Bed Series in type section and Chuarta area. 


\section{REFERENCES}

Al-Barzinjy, S.T.M., 2005. Stratigraphy and Basin Analysis of Red Bed Series from Northeastern Iraq, Kurdistan Region. Unpublished Ph.D. thesis, University of Sulaimani, $159 \mathrm{p}$.

Al-Hashimi, H.A.J. and Amer, R.M., 1985. Tertiary Microfaciesof Iraq Directorate General of Geological Survey and Mineral Investigation Baghdad. 56 p.

Al-Mehaidi, H.M., 1975. Tertiary Nappe in Mawat Range, N.E Iraq, Jour. Geol. Soc. Iraq, vol. 8, pp.31-44.

Al-Omari, F.S. and Sadiq, A., 1977. Geology of North Iraq. Mosul University Press. $198 \mathrm{p}$.

Al-Rawi, Y., 1982. Carbonate-Rich Sandstone: Occurrence, Classification and Significance. Iraqi Jour. Sci. Vol. 23, No. 3. pp.23-33.

Baziany, M.M.Q., 2006. Sedimentology and Stratigraphy of Qulqula Conglomerate Formation, Kurdistan Region, NE-Iraq. Unpublished M. Sc. thesis, University of Sulaimani, $103 \mathrm{p}$.

Bolton, C.M.G., 1958d. The Geology of Ranyia area. Site Inv. Co. Upubl. Report, SOM Library, Baghdad.

Buday, T., 1980. The Regional Geology of Iraq: Vol. 1, Stratigraphy: I.I.M Kassab and S.Z. Jassim (Eds) D.G. Geol. Surv. Min. Invest. Pub. 445 p

Buday, T. and Jassim, S.Z., 1987. The Regional Geology of Iraq: Vol. 2, Tectonis Magmatism, and Metamorphism. I.I. Kassab and M.J. Abbas (Eds), Baghdad, $445 \mathrm{p}$.

Folk, R.L., 1974. Petrology of Sedimentary Rocks. Hemhill Pub. Co. Texas, 182 p.

Jassim, S.Z. and Goff, J.C., 2006. Geology of Iraq. Published by Dolin, Prague and Moravian Museun, Brno. 341 p.

Karim, K.H. and Surdashy, A.M., 2005. Tectonic and Depositional History of Upper Cretaceous Tanjero Formation in Sulaimanyia area, NE-Iraq. Journal of Iraqi Science, Vol. 5, No. 1, pp.30-44.

Pettijohn, F.J., 1975. Sedimentary Rocks. Third Edition, Harper and Row Publ. Co., $627 \mathrm{p}$.

Sissakian, V.K., 1997. Geological Map of Arbeel and Mahabad Quadrangles. Sheets NJ 38- 14 and NJ-38-15., Scale 1:250000, State Establishment of Geological Survey and Mining. GEOSURV, Baghdad, Iraq.

Sissakian, V.K., 2000. Geological Map of Iraq. Sheet No.1, Scale 1:1000000, State Establishment of Geological Survey and Mining. GEOSURV, Baghdad, Iraq.

Sissakian, V.K., 2005. The Stratigraphy of the Exposed Cretaceous Rocks in Iraq, as deduced from the Results of the Regional and Detailed Geological Survey (Geosurv 1971-1996). Iraqi Bulletin of Geology and Mining.Baghdad.Vol.1, No.1, pp.1-20.

Stocklin, G., 1974. Possible Ancient Continental Margin in Iran, in Burk, C.A. and Drak C.L. (Eds). The Geology of Continental Margins, Springer Verlage. New York, pp.873-887.

Surdashy, A.M., 2001. Paleoenvironmental Reconstruction by Calcareous Algae at Paleocene-Early Eocene in Northeastern Iraq. J ZS, Vol.4, No.1, pp.101-116. 